\title{
IJBF INSIDER TRADING AND LARGE CHAPTER 11 BANKRUPTCIES IN USA
}

\author{
Tareque Nasser and Benton E. Gup \\ The University of Alabama
}

\begin{abstract}
The Enron and WorldCom debacles raised questions about the state of corporate governance in the United States. Insider trading is one aspect of corporate governance highlighted in these cases. In this paper, we explore insider trading of large Chapter 11 bankruptcy filing firms during the twelve-year period of 1995-2006. We find that insiders in these firms, on average, do not use private information for gain or loss avoidance.
\end{abstract}

Keywords: Insider trading, Bankruptcy, and Corporate governance JEL classification: G32, G34

\section{Introduction}

Several large firms that filed for bankruptcy in recent years used unscrupulous accounting and business practices including, but not limited to, insider trading. For instance, several executives of WorldCom were either convicted or had confessed to fraud and illegal insider trading. Bernard Ebbers, Chief Executive of WorldCom, was sentenced to 25 years in prison for orchestrating his $\$ 11$ billion fraud of the bankrupted telecommunication giant. ${ }^{1}$

Similarly, after confessing to fraud and illegal insider trading, some Enron executives too were convicted. As a result, lawmakers passed the Sarbanes-Oxley Act in order to enforce corporate governance. Insider trading is one aspect of corporate governance that needs to be examined. In this paper we explore insider trading in large American publicly traded firms with assets of $\$ 1$ billion or more that filed for Chapter 11 bankruptcy protection in the test period.

Both the Securities and Exchange Commission (SEC) and academic researchers refer to a firm's chairman, directors, officers, and principal shareholders with 10

1 Dionne Searcey, Shawn Young \& Kara Scannell, "Ebbers Is Sentenced to 25 Years For \$11 Billion WorldCom Fraud", Wall Street Journal (Eastern edition), New York, N.Y., Jul 14, 2005. pg. A.1. 
percent or more of any equity class of securities as the insiders. ${ }^{2}$ The term insider trading includes both legal and illegal conduct. The SEC considers insider trading as legal when corporate insiders buy and sell stock in their own companies without violating any rules laid out to protect the general investors' interest. Similarly, the SEC characterizes illegal "insider trading" as the buying or selling of securities by any insider in breach of a fiduciary duty or other relationship of trust and confidence, while in possession of material, nonpublic information about the security. Insider trading violations may also include "tipping" such information to an individual and securities trading by those who misappropriate such information. However, these tip-initiated trades are not documented and filed with the SEC as insider trading. The phrase insider trading in finance literature is often used both in the general sense and as the illegal use of private information for personal gain. In most cases it is the latter. It is generally assumed that readers can distinguish between the two from the context of the discussion.

When there are no prohibitive insider trading rules, insiders may have ample incentive to take advantage of their private information. So, the actual magnitude and pervasiveness of insider trading depends upon the trade-offs between the benefits and costs that insiders observe and perceive. The Securities Exchange Act of 1934 (hereafter, 1934 Act) was enacted to insure a "fair and honest" market. The abusive use of private information by insiders is dealt in three ways (Bettis, Duncan, and Harmon, 1998):

1. Insiders are obligated to disgorge any profit from the buying and subsequent selling of securities within a six-month period, even if the trade is not based on private information. This is known as the short-swing rule.

2. There are numerous reporting requirements by insiders such that any trading undertaken by insiders is transparent. Insiders of the publicly traded companies need to report their trades and changes in ownership to the SEC using three different Forms. ${ }^{3}$ These are Forms 3, 4, and 5.

a. Form 3 is the initial statement of beneficial ownership for all officers.

b. Form 4 reports change in an insider's ownership position.

c. Form 5 is the annual statement of change in beneficial ownership.

In addition to the above three Forms, Form 144 is the insider's declaration of their intention to sell restricted stock.

2 The legal definition of a corporate insider is any person who is obligated to report and file his/her securities trading with the SEC. They include a company's officers and directors, as well as any beneficial owners of more than ten percent of a class of the company's equity securities registered under Section 12 of the Securities Exchange Act of 1934.

3 Previously, insiders were to report any changes in their holding by the $10^{\text {th }}$ day of the following month. However, after the Sarbanes-Oxley Act of 2002, insiders are required to report their trade within two business day after the trade has occurred. 
3. It is unlawful to use any private nonpublic information to make profit through trading. In fact, the Insider Trading Sanction Act of 1984 (ITSA) and Insider Trading and Securities Fraud Enforcement Act of 1988 (ITSFEA) require more severe civil and criminal penalty for insider trading. ISTA stipulates that the penalty that may be imposed is determined by the court in light of the facts and circumstances, but should not exceed three times the profit gained or loss avoided as a result of such unlawful purchase, sale, or communication. The ITSFEA allows criminal fines up to $\$ 1,000,000$ from individuals, and maximum jail up to 10 years. How effective the SEC has been with discouraging insider trading is a question explored in many studies with mixed evidence (Seyhun, 1992; Bettis et al. 1998; Bris, 2005).

Here, we attempt to add to the literature concerning the state of insider trading in large U.S. corporate firms facing bankruptcy. We seek to examine a sample of 129 large firms that filed for bankruptcy over the period of 1995-2006. Appendix A lists out the names of these 129 firms, their bankruptcy filing date, and the asset size prior to bankruptcy. All these firms had assets over a billion dollars two years prior to their bankruptcy filing. Although a total of 137 firms met the criteria of our sample selection, we had to drop 8 firms because of data limitations.

Table 1 shows some characteristics relating to the bankruptcy for all of the 129 firms. In this table, "fraud" implies bankruptcies caused by fraud claims (including securities fraud claims) against the company. These cases often began with financial difficulties from other causes, which were concealed from the investors until they were severe enough to cause the bankruptcy. "Disposition" is the outcome of the bankruptcy case. "Confirmed" means that the court confirmed a plan of reorganization. The term " $\$ 363$ sale" means that the debtor sold all or nearly all of its assets during the Chapter 11 case. ${ }^{4}$ "Pending" means that the case remains pending in the bankruptcy court. "Emerged" means that the company has either emerged as it was before the bankruptcy or as some other form (i.e., taken over or merged with some other firms), but did not die out.

As shown in Table 1, 123 out of the 129 firms sampled had their Chapter 11 bankruptcy case filed by the debtor, 5 by the creditors, and 1 by both the debtor and creditors. Note that 10 out of the 129 firms shown in Table 1 had committed fraud, which ultimately led to bankruptcy. ${ }^{5}$ Out of these 10 firms, 8 firms emerged from bankruptcy. One firm did not survive, while another's case is still pending.

4 Usually, if a Chapter 11 debtor wanted to sell all or nearly all of its assets, it would do so through a plan of reorganization or a plan of liquidation. Lately however, Bankruptcy Courts have permitted such a sale based on Section 363 of the Bankruptcy Code prior to the plan solicitation and confirmation process, so long as certain requirements are satisfied. This is commonly known as the " $\$ 363$ sale".

5 The 10 firms that filed for Chapter 11 because of fraud are indicated in Appendix A with the symbol *.

Source: Lynn M. LoPucki's Bankruptcy Research Database (WebBRD). 
Table 1: Characteristics of 129 Sample Firms Filing for Chapter 11 During 19952006

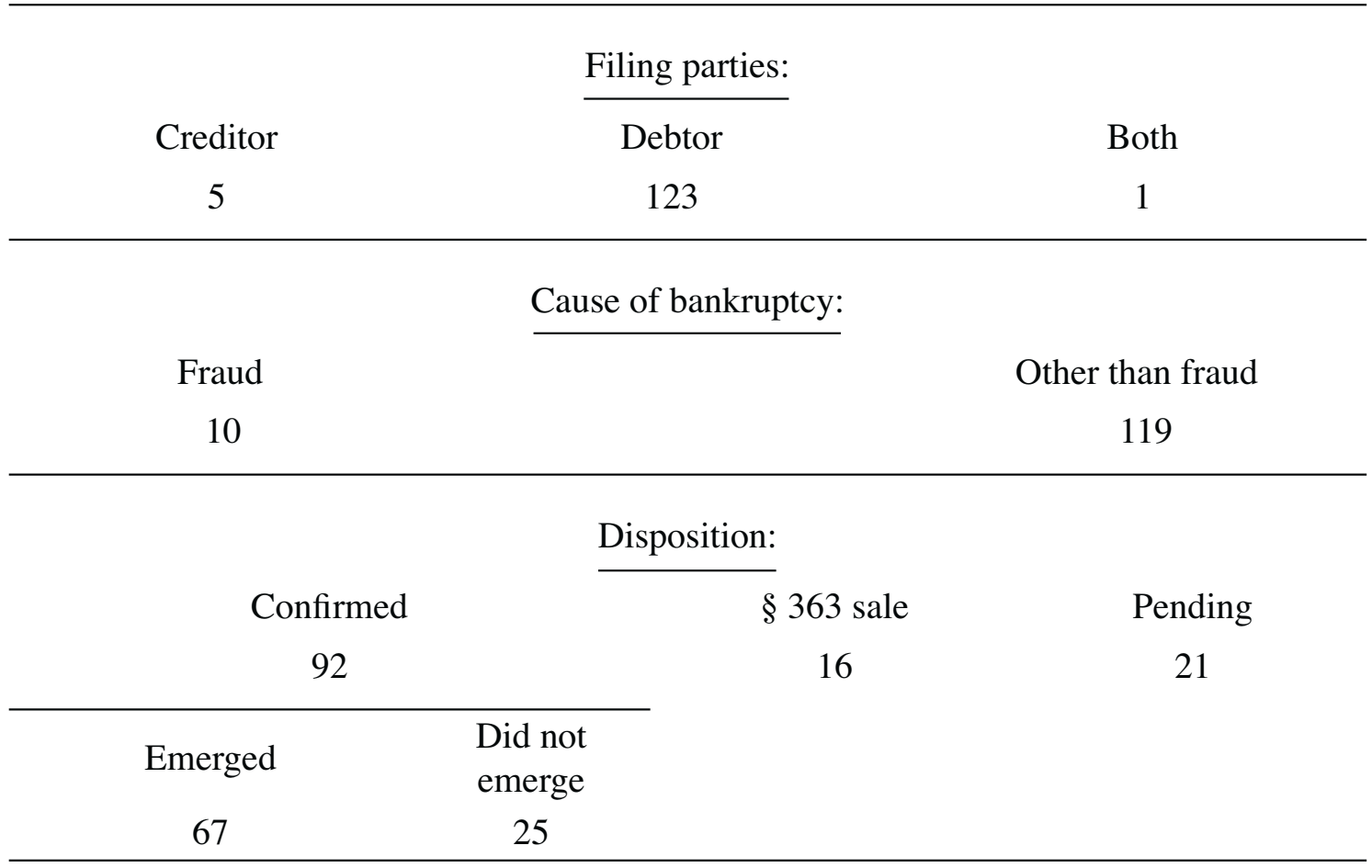

Source: Lynn M. LoPucki Bankruptcy Research Database (WebBRD).

The bankruptcy courts have confirmed reorganization plans for 92 firms, while 21 cases are pending trial. The remaining 16 firms of the 129 firms went though the " $\$ 363$ sale." Out of 92 firms whose reorganization/liquidation plans have been confirmed by the bankruptcy court, 67 emerged as either the same firm as before or in some other form, while 25 firms did not survive.

Interestingly, none of the firms whose insiders were charged with fraud went through a " $\$ 363$ sale". This implies that at least some of the insiders of the 50 firms were at risk of losing their jobs because of either fraud or dissolution. ${ }^{6}$ On the other hand, it is usually the firms that file for the Chapter 11 bankruptcy, not the creditor. These facts suggest that there were several reasons why insiders were unlikely to do trading based on insider information. Firstly, illegal insider trading is punishable by incarceration; secondly, losing their job because of illegal insider trading may impair their future employability; and thirdly, the Chapter 11 bankruptcy process may enable managers to save their job at the time of financial distress.

In this paper, we compare the level of insider trading of large firms filing for bankruptcy to a set of control firms. We find that insiders of firms filing for bankruptcy do not significantly sell more or buy less than the control firms in similar

$6 \quad(50=10+25+16-1)$. The number of bankruptcy filings caused by fraud $=10$; number of firms whose reorganization/liquidation plan was confirmed, but did not survive $=28$; number of firms that went through " 363 " sale $=15$; and number of firms that committed fraud and did not survive $=2$. 
industries. Both the number of trading insiders and the dollar volume of trading in each quarter, for 8 quarters, before the bankruptcy filing date, measure insider trading.

Section 2 aims to discuss the relevant literature for our study, while Section 3 covers the data and methodological issues measuring insider trading. Section 4 describes our own study and its results, with Section 5 naturally providing the conclusion.

\section{Review of Literature}

\subsection{Insider Trading in the Event of Bankruptcy}

Although not focused on illegal insider trading, numerous academic studies report that insiders earn abnormal returns. ${ }^{7}$ Alternatively, many studies document the presence or absence of insider trading around various corporate events or public announcements. For instance, Elliot, Morse and Richardson (1984) had tested whether insiders trade profitably before the public release of earnings, dividends, bond ratings, mergers, and bankruptcies. They had found that most insiders' trading was not related to these events. Penman (1982) on the other hand, found that insiders do time their trade according to the annual earning forecast disclosure date, earning abnormal returns. Karpoff and Lee (1991) had found that insiders sell shares prior to new equity issues, while Harlow and Howe (1993) had found that insiders accumulate shares abnormally prior to management buyout.

Similarly, the question of whether insiders take advantage of material, nonpublic information of the impending bankruptcy has yielded mixed results. Loderer and Sheehan (1989) do not find insiders "bailing out" of the firm. In contrast, Gosnell, Keown, and Pinkerton (1992) had found that insider selling increases significantly as the bankruptcy announcement approaches, particularly for over the counter (OTC) traded firms.

Seyhun and Bradley (1997) had found that insiders systematically sell and buy stocks around the bankruptcy event to make abnormal profits. Ma (2001) however, found that there is not much selling by insiders before bankruptcy. But there is the significant lack of purchases by the insiders before the bankruptcy. Iqbal and Shetty (2002) had viewed the problem a little differently. They had found that there exists significant insider trading around the month when the market anticipates the bankruptcy, not around the month when the bankruptcy filing is announced.

\subsection{Motivations for Insider Trading}

The extent of insider trading depends upon the expected benefits and costs, whether they can foresee the future bankruptcy. In an experimental study using college students, Beams, Brown, and Killough (2003) had found that the subjects are more likely to trade based on insider information to avoid loss than to achieve abnormal

7 See, for instance, Jaffe (1974); Seyhun (1986); Rozeff and Zaman (1988); Lin and Howe (1990); Meulbroek (1992); and Lakonishok and Lee (2001). 
gain. It is often difficult to pinpoint whether a particular trade is motivated by selfish personal gains, or if it is carried out to implement the implicit compensation contract for the insiders. Recent, notorious bankruptcy cases are examples where insiders resorted to illegal measures for personal gains at the expense of the shareholders.

It is often not clear whether insider trading (in a general sense) is a result of an agency problem or whether it reduces agency problems. It can be argued both ways. Carlton and Fischel (1983) had argued that the ability of an agent to exploit his/her informational advantage could be part of the implicit or explicit contract between the shareholder and the agent. In fact, trading allows an agent to renegotiate the contracts when underlying conditions change (Dye (1984). However, Fischer (1992) had argued that when there is an agency problem, trading by the agents might in turn aggravate the agency problem. Fischer (echoing Easterbrook, 1981), argued that the uncertain compensation through trading results in suboptimal risk sharing. Also, the agents may have added an incentive to cook the books and take actions that may create profitable trading opportunities for agents at the expense of shareholders.

When bankruptcy occurs, there is high probability the insiders can lose their jobs and any other associated quasi-rents. This may prompt them to take actions consistent with what Fischer (1992) had argued, particularly in absence of significant, legal deterrence mechanisms. Moreover, if the insiders bail out by selling their stock, the subsequent restructuring process may not be in the best interest of the other shareholders. Stockholders' gains are directly related to the insiders' holding because the insiders' wealth is at stake Betker (1995).

\subsection{Chapter 11 Bankruptcy and Insider Trading}

Under U.S. bankruptcy laws, firms have a choice between filing for Chapter 7 and Chapter 11, where they go through liquidation and reorganization processes, respectively. Under Chapter 7, a firm ceases its business immediately, and goes through the liquidation process by an appointed trustee to pay off its debts. Whereas under Chapter 11, the incumbent managers still remain in control as the firm continues to operate for the duration of the reorganization process. At the same time, a reorganization plan is adopted through which all pre-bankruptcy claims are settled or renegotiated. However, management with strong bargaining power can pressure the creditors to accept their terms [White (1989), and managers bargaining power is the greatest when firm is close to solvency (Betker (1995)]. It is also interesting to note that during the Chapter 11 bankruptcy process, the only way the stockholder's interest is represented is by the management. ${ }^{8}$ Betker (1995) had reported how courts have held that shareholders cannot hold a meeting to replace the directors of insolvent firms. All these facts point out that the invoking Chapter 11 bankruptcy process is a wonderful opportunity for the managers to save their jobs, while at the same time, retain significant bargaining power when the firm is on borderline solvency.

Bradley and Rosenzweig (1992) had stated that “...Chapter 11 does not require that a debtor be insolvent in order to qualify for reorganization, and it includes a strong presumption favoring retention of management throughout the reorganization

8 This obviously involves deviations from absolute priority in Chapter 11 bankruptcy. 
process. Thus, in the ordinary case, a Chapter 11 filing transforms a corporate debtor into the "debtor-in-possession" and leaves existing management in control of the firm's resources." If management is relatively certain that the bankruptcy restructuring process is just a temporary adjustment to solidify their grip on the reign of the firm, we can expect that there would be no insider trading. This is even more pertinent to big firms as it is often believed that they are "too-big-to-fail."

\subsection{Impediments to Insider Trading}

Many public companies have policies governing the trading of their securities by officers, directors, and employees, with the goal of preventing trades at times when insiders may be in possession of material nonpublic information (Bettis, Coles and Lemmon, 2000). Such policies are designed to ensure compliance with securities trading prohibitions. They generally contain periodic "window periods" or "blackout periods" tied to the company's announcements of financial results or other corporate developments. During window and blackout periods, trades by insiders are conditionally permitted or prohibited, respectively.

Bettis et al. (2000) had reported that although firms are not required by law to implement periodic insider trade restricting policies. The absence of such policies may be deemed as a reckless conduct by the firms from the regulator's point of view. Insider trading policies often require insiders to obtain an advance trading clearance with a designated member of the management. Public companies normally include trading windows or trading blackout periods in insider trading policies to prevent insiders from trading at or around the time of earnings announcements or the dissemination of other sensitive corporate information.

In the event of job loss due to bankruptcy, managers want to preserve their future employment opportunities. LoPucki and Whitford (1993) had argued that managers could not breach their fiduciary duty at the expense of the firm because they may be stigmatized, which in turn, may adversely affect their marketability. However, LoPucki and Whitford did not discount the possibility of some unscrupulous insiders who resort to illegal means for immediate gain at the expense of shareholders and their own future human capital loss.

To a certain extent, the incidence of informed insider trading also depends upon the corporate governance system in place. For instance, Becht, Bolton, and Roell (2003) had asserted that executive stock options (ESO) “... are at best an inefficient financial incentive and at worst create new incentive or conflict-of-interest problems of their own." They had also criticized other mechanisms of corporate governance for their inability to exert corporate control. Holmstrom and Kaplan (2003) however, had responded by stating that this is an exaggeration. They had argued that although there were instances of stock price manipulation because of the ESO carried out by firms like WorldCom, these are by no means representative.

Holmstrom and Kaplan had contended that the U.S. corporate governance system with the recent regulatory overhauling like Sarbanes-Oxley Act of 2002 (SOX) is "...likely to make a good U.S. system [a] better one." Bettis et al. (2000) had investigated the corporate policies restricting insider trading, reporting that by November 1996, 92 percent of their sample firms have instituted policies to restrict 
and manage insiders' trading, with 80 percent of the sample firms having explicit blackout periods prohibiting insider trading. Thus, the extent to which the corporate control mechanisms deter insider trading is an empirical question.

\subsection{Laws and Insider Trading}

The deterrence of informed insider trading requires both good corporate control and effective enforcement of insider trading regulations. Effective enforcement does not necessarily imply a total prohibition on inside trading. For instance, Shin (1996), while modeling an optimal regulation of insider trading, had concluded that in the presence of research-informed market professionals, some insider trading is better than a total ban on insider trading to help decrease the loss of liquidity traders. Similarly, DeMarzo, Fishman and Hagerty (1998) had recognized that effective insider trading regulation requires monitoring and enforcement in a market setting.

However, in doing so, regulators must use market data that is very costly to decipher. Based on their model, they had concluded that it is optimal for the regulators to investigate if and only if trading volume exceeds some threshold, where the threshold depends on the information released concerning share value. DeMarzo et al. had also proposed that if the insider is caught trading more than above a certain critical level, then he/she must pay the maximum, feasible penalty.

A study conducted by Bris (2005), based on data from 52 countries, had found that the incidence and profitability of insider trading increases with the enforcement of insider trading laws. He had measured insider trading before the tender offer announcement and found that after some enforcement of insider trading laws, insiders had appropriated a larger portion of the takeover gains. However, he had concluded that harsher laws work better in reducing insider trading. Bris had found that the U.S., among all 52 countries, has the toughest insider trading regulation and the lowest profit for the insiders. Most academic studies on insider trading deterrence concluded that harsher penalties discourage insider trading. It seems that the U.S. legal system is going towards a harsher penalty over major insider trading and frauds as evidenced at the beginning of this paper.

Agrawal and Jaffe (1995) had reported that even though the SEC may not actively prosecute short-swing trades, lawyers generally challenge them if they perceive the prosecution to be profitable. Agrawal and Jaffe had explained that all these lawyers have to do is to buy a share of the company where they find any violations of the short-swing rule and file the suit as a shareholder. When successfully prosecuted, they received the legal fees from the trading profits that the insider returns to the firm.

Based on the previously cited studies, we infer that the two most likely types of illegal insider trading involves:

1. small trades that fall into the category of short-swing trades and those that the regulatory authority may overlook;

2. large trades that result of gross breach, fiduciary duties. Insider-trades of intermediate size are not worth the risk of getting caught at the expense of future economic and human capital loss. 


\section{Methods and Data}

\subsection{Measuring insider trading}

\subsubsection{Use of Purchases and Sales Information to Measure Insider Trading}

One of the earliest measurements of insider trading conducted by Lorie and Niederhoffer (1968) is based on identifying an intensive selling month or buying month, and then measuring the market price movement in the six months subsequent to the event. They define an intensive selling (buying) month as a month with at least two more sellers (buyers) than buyers (sellers) among the insider of a company. However, Lorie and Niederhoffer do not measure the presence of insider trading around any particular corporate event or information released; rather, they simply attempt to establish its existence.

Jaffe (1974) had used a modified method to measure insider trading. He computed the number of net buyers ${ }^{9}$ and sellers for each firm during a randomly picked month. He then defined a month as a "month of net purchasers" if the number of net buyers is more than the number of net sellers, similarly defining the "month of net sellers." He had regarded these months as information based trading events. Jaffe had then employed a technique similar to the event study methodology developed earlier by Ball \& Brown (1968) and Fama, Fisher, Jensen, and Roll (1969) to measure the abnormal return.

\subsubsection{Using CAR to Assess Insider Trading}

The use of abnormal returns and cumulative abnormal returns (CAR) is widely recognized in academic studies. Seyhun and Bradley (1997) had based their whole insider trading argument using event study methodology in several ways. One obvious way they had implemented the event study method is to measure the abnormal returns and CAR. However, Seyhun and Bradley had altered the standard event study method to take account of some unique features of the data during the event of bankruptcy. For example, it is quite normal that before bankruptcy is announced, several firms either cease trading of their shares temporarily or they are delisted altogether. Also, when the prices fall to single digit levels, standard CAR estimates may grossly misrepresent the true abnormal return over the period. For these reasons, instead of using a standard market model, Seyhun and Bradley had used a bootstrapping method to calculate the mean abnormal holding period return over different periods. ${ }^{10}$ Another way they use the event study method is to compute abnormal insider trading, where instead of returns, they measure insider trading in trading volume.

9 A net buyer here is if an insider buys more days than sells in a month. A net seller is defined analogously.

${ }^{10}$ Seyhun and Bradley (1997) had measured the abnormal returns, the difference between the return of the investing portfolio of firms that filed for bankruptcy, and the average return of the bootstrap distribution for the set of control firms' bankrupt portfolios. 


\subsubsection{Setting the Benchmark Level of Insider Trading}

While measuring insider trading, it is crucial to establish a normal insider-trading level that accounts for portfolio rebalancing, liquidity needs, or any other reasons except private information based trading. Most "abnormal" insider trading is evident by documenting any significant excess trading, lack of trading, or deviations from the normal level in the direction indicated by the nature of the information. Therefore, how the researchers account for the normal level of trading is reflected in their methods they had implemented. In many cases, the normal level of trading is established using a set of control firms. Typically, it involves matching the subject firms' two digit SIC code, while controlling for size in terms of either asset size (see Loderer and Sheehan, 1989) or market capitalization (Gosnell et al., 1992 and Ma, 2001). The matching is generally done based on data related to the above; that is, two to five years prior to the event.

Seyhun and Bradley (1997) had criticized this method. Firstly, they had picked a set of control firms from the same industry with similar problems (e.g. financial distress). Secondly, with bankruptcy, the subject firms may shrink in size over the period, creating a size disparity between the subject and the control firms. However, Seyhun and Bradley (1997), with their modified use of event study to measure abnormal insider trading, did not bypass the use of control firms. In their study, Seyhun and Bradley had centered the time series of the insider trading data on the event date, and then measured the average trading per firm for each month over the event window. Here, they had designated sales as a negative number and purchase as a positive number.

They had measured the abnormal insider trading (both in number of shares traded and in dollars) for each period (in months) as the difference between the actual trading activity for a given firm and the amount of insider trading activity of a "control portfolio" of similar sized firms over the same period. They had constructed these control portfolios by first calculating the mean annual equity value of all firms reporting any insider trading activity over their study period. Then, they had ranked these firms, excluding the subject sample firms, according to market capitalization, categorizing them into deciles. Using this method, they had created the "expected" insider trading data for portfolios of firms of each size decile and insider category for each month over the study period.

However, we believe that judiciously choosing the time of matching (i.e., not too far away from the event time) may alleviate the size disparity problem significantly, neglecting those similar methods as adopted by Seyhun and Bradley. Furthermore, Agrawal and Jaffe (1995) had argued that matching based on two-digit SIC classification is broad enough to have little or no effect on the control firm's event.

\subsubsection{Bypassing the Control Firms to Assess Insider Trading}

Many researchers forgo the use of control firms altogether by trying to establish the normal level of insider trading by using time series data. Karpoff and Lee (1991) had developed such a technique, while those by the likes of Harlow \& Howe (1993), Iqbal \& Shetty (2002), and Irani (2003) have used it. Karpoff and Lee 
(1991) had derived the mean abnormal and the cumulative number of net sellers and associated statistics to assess the abnormal number of net sellers in the event of new issues of common stock. Harlow and Howe (1993) on the other hand, had used the same method to find the abnormal number of net buyers for leverage buyout announcements.

When researchers do not use control firms, they use other approaches. One general approach used by Finnerty (1976), Penman (1985), John and Lang (1991), and Lakonishok and Lee (2001) had involved the development of indices or ratios. The typical way of constructing these would be computing ratios as $\frac{P-S}{P+S}$ or $\frac{P-S}{(P+S) / 2}$ or some other complicated variations. Here, $P$ may represent the number of insiders purchasing stock, the number of purchasing transactions, the number of shares purchased, the dollar value of transactions, or any other construct that researchers feel would convey information related to the study. Similarly, $S$ would represent any of the above corresponding constructs related to sales. These ratios were used in different regression equations to explain returns or abnormal returns, thereby, evaluating insider trading.

\subsubsection{Method Used in this Paper}

Many researchers believe in the efficacy of control firms for benchmarking purposes. Of course, the form of analysis may differ considerably. For instance, while assessing insider purchases around merger announcement, Agrawal and Jaffe (1995) had used matched control firms in addition to time-series controls. They had used matchedpair $t$-statistics for measuring the cross-sectional difference between the means of the target and control firms. However, Ma (2001) had argued that insider-trading activity is quite infrequent, non-normal, and highly skewed in magnitude, thus calling for statistical analysis that does not require distributional assumptions. He argued that non-parametric methods are suitable for this purpose. Hence, he used the Wilcoxon signed-rank test (which is a non-parametric technique) to compare insider-trading measures of bankruptcy firms with those of the control firms. We use this method in our study along with other descriptive statistics.

The next obvious issue is the appropriate measures of insider trading. Agrawal and Jaffe (1995) had used several measures for insider trading. These are the number of insiders who buy in a given period, shares purchased in a period, dollar value of purchase, and percentage of equity bought; whereas, Ma (2001) uses the number of transactions, number of insiders, and dollar amount of trade. Other measures like percentage of outstanding equity purchased, percentage of total share purchase volume, and percentage of total dollar purchase volume are also used in the literature.

Against this background, we concentrate on two constructs:

1. the number of insiders buying or selling each quarter; and

2. the purchases or sales in dollars (trading volume) for each quarter.

The number of insiders helps to explain how widespread insider information utilization is present within the firm. Generally, we do not expect many insiders trading at the same time unless there is some motivating reason, such as the awareness of price changing information. Hence, if we see that the number of insiders who 
are trading in a particular period is significantly higher, it may be because of inside information. For instance, if we find the number of insiders that are selling in a particular quarter for the firm filing for bankruptcy is abnormally high, then it is evidence of insider trading.

Finally, trading volume captures the magnitude of use of insider information. We will use these two constructs at the same time. If only one of them is significant, while the other is not, it is not a strong case of insider trading. However, if both are significant at the same time, it is strong evidence of insider trading.

\subsubsection{Justification of the Method Used in this Paper}

Although there is no clear cut evidence that any one method described above is superior to others, we selected the method used in this paper for several reasons. Firstly, we were in search of a simple proven test to measure the extent of insider trading. The method that we had adopted meets this criterion.

Secondly, we avoid the usual criticism of the use of control firms to set normal insider trading levels. Later, we will show how the criticism of Seyhun andd Bradley (1997), in using control firms from the same industry may produce firms with similar problems like financial distress, is absent in the control sample. Moreover, Seyhun and Bradley's other objection in using control firms was that the subject firms might shrink in size over the period, creating a size disparity between the subject and the control firms. They had avoided this by using shorter time periods (i.e., using two years prior data instead of five years prior data for the matching process).

Thirdly, insider-trading activity is infrequent, non-normal, and highly skewed in magnitude. Hence, using a non-parametric technique like the Wilcoxon signedrank test, we can do away with the distributional assumption that is needed for other statistical techniques.

\subsection{Data}

\subsubsection{Sources of Sample Firms}

Professor Lynn M. LoPucki's Bankruptcy Research Database (WebBRD) ${ }^{11}$ provides an extensive listing of firms that filed for bankruptcy in the U.S. bankruptcy courts. It also has a data query, web interface, where researchers can get lists of bankruptcy filing firms with a variety of specifications. We used this web query to get a list of firms that had an asset size greater than or equal to a billion dollars prior to filing for bankruptcy during the 1995-2006 period. The asset size of the firms filing for bankruptcy in the WebBRD is recorded in current dollars.

However, we also further screened these firms based on the criterion that firms should have asset size, as reported in Compustat, over a billion dollars two years prior to filing for bankruptcy. This criterion is imposed to ensure that there is no mistake in the asset size reported in the WebBRD, ${ }^{12}$ as well as the fact that we had decided

\footnotetext{
${ }^{11}$ Researchers who want to know more about WebBRD's data sources and quality may browse (http://lopucki.law.ucla.edu/frequently_asked_questions.htm).

${ }^{12}$ We found some discrepancies between the asset size reported in WebBRD and Compustat, after accounting for current dollars conversion.
} 
to use matched control firms based on asset size and industry for our analysis. ${ }^{13}$ It yielded 137 firms. Unfortunately, we were not able to get the insider trading data for 8 firms. Hence, our final sample includes 129 firms that had assets of more than a billion dollars that filed for bankruptcy during the 1995-2006 period.

\subsubsection{Getting the Insider Trading Data}

Most of the previous studies surrounding insider-trading used data from the Ownership Reporting System (ORS) or the Official Summary of Securities Transactions and Holding, which is published by the SEC. Currently, Thomson Financial provides the same information through TFN Insider Filling Data (TFN Insiders). We used the Thomson Financial Insiders Data (TFN Insiders) to get the insider trading data. Note that it is possible that some insiders buy and sell their securities without reporting their trade to the SEC (Meulbroek, 1992). However, we have no information on either accepting or refuting such activity. Hence, the data that we are using is based on only the reported trades.

To extract the appropriate data, we needed each firm's corresponding CUSIP Issuer Code (CUSIP6), and the date when they filed for bankruptcy. WebBRD only provides the bankruptcy-filing year without the exact filing date. Therefore, we obtained the bankruptcy filing date by searching the 10-K Wizard SEC filings. When these were not available in the 10-K Wizard, we obtained the Chapter 11 filing dates through web browsing different news sources and "BankruptyData. com." The CUSIP6 was derived from matching each firm's name within Compustat and CRSP.

We obtained insider-trading data for the 129 firms in our sample covering a two-year period prior to the bankruptcy from TFN Insiders. We only use the open market purchases or sales data in TFN Insiders, excluding purchases related to options exercises. Insider trading activity equals zero for any firm that has a registered insider documented by TFN Insiders, but has no open market trades reported by TFN Insiders during the sample period. We exclude trades that buy or sell fewer than 100 shares or with a total value exceeding \$100. Trades lacking transaction prices in TFN Insiders are excluded from our sample.

We use trading data for two years prior to the filing for bankruptcy. Although we believe that insiders cannot foresee the actual bankruptcy as far as two years down the road, we still use the two-year time span, since it is the shortest period used in the previous literature.

\subsubsection{Constructing the Set of Control Firms}

Like previous studies, we used a set of control firms to assess the prevalence of insider trading. Given the choice between matching control firms based on market capitalization and asset size, we opted for the latter for two reasons:

1. we picked our sample firms based on asset size;

${ }_{13}$ As it will be explained later in the paper, we matched asset sizes for two years prior to bankruptcy using Compustat Industrial Annual and a 2-digit SIC code to get the control firms. 
2. rapidly growing firms can have a market capitalization that is equal to or greater than that of some mature firms that are growing slowly or shrinking (Gup and Agrawal, 1996).

Thus, market capitalization, per se, can be misleading when comparing across the two samples. Consequently, we matched asset sizes for two years prior to the bankruptcy using Compustat Industrial Annual and a 2-digit SIC code to get the control firms.

Although, we could obtain a match for most of the firms, if the firm's asset size was missing in the two-year priors to bankruptcy, we used one-year prior data. Also, if the closest match was an ADR of some foreign firm, another bankruptcy filing firm, or a firm not in the TFN Insiders, then we found the next closest match in asset size.

Table 2: Comparison of Bankrupt Firms and Matched Control Firms

\begin{tabular}{|c|c|c|c|}
\hline \multicolumn{4}{|c|}{ Panel A: Summary statistics of asset size (in million dollars) } \\
\hline & Bankrupt firms & Asset matched firms & Difference \\
\hline $\mathrm{N}$ & 129 & 129 & 129 \\
\hline Mean & 6,614 & 6,375 & 554 \\
\hline t-test & \multicolumn{2}{|c|}{1.2363} & \\
\hline Median & 2,579 & 2,399 & 79 \\
\hline Wilcoxon sign-rank test & \multicolumn{2}{|c|}{0.858} & \\
\hline Std. Dev. & 12,167 & 12,018 & 2,131 \\
\hline
\end{tabular}

Panel B: Number of firms with zero trading

\begin{tabular}{lcc}
\hline & Bankrupt firms & Matched Firms \\
\cline { 2 - 3 } Purchase & 29 & 31 \\
Sales & 28 & 21 \\
Both & 16 & 13 \\
\hline
\end{tabular}

None of these statistics are acceptable at the normal confidence levels.

The descriptive statistics of the sample bankrupt firms and their control counterparts are shown in Panel A of Table 2. The mean and the median of the bankruptcy sample firms' asset size are \$6,614 and \$2,579 million, respectively. For their matched control firms, they are $\$ 6,375$ and $\$ 2,399$ million dollars, respectively. The standard deviation of the asset size for the subject firms is $\$ 12,167$ million and for the control firms is $\$ 12,018$ million. The $t$-test for the mean difference and the Wilcoxon sign-rank test for the median difference are not statistically significant in any of the commonly used significant levels. Hence, the asset size distributions of both the samples are similar. 
As shown in Panel B of Table 2, 16 firms had no insider trades for two years prior to their bankruptcy. For the matched firms, 13 firms had no insider trading during the same period. Based on Panel B of Table 2, we find that $41(29+28$ - 16) of the bankrupt firms have no insider purchase and/or sales during the period under examination. The corresponding number for the matched control firms is 39 $(31+21-13)$. This implies that more than $30 \%$ of the bankrupt firms and their corresponding control firms had no insider trades for the two years prior to the filing date. Stated otherwise, insider trading is an infrequent activity.

\section{Results and Analysis}

We cannot talk about the existence of insider trading before we look into the abnormal returns. It is obvious that significant, negative abnormal returns prior to bankruptcy filings provide the motive for insider trading. Panel A of Table 3 shows average cumulative abnormal returns (CAAR) of the bankrupt firms over different periods. ${ }^{14}$ These are calculated based on the OLS market model using the CRSP Equally Weighted Index. For the 58 trading days, the period starting 60 days before the date the firm filed for bankruptcy and ending 2 days before the filing date relative to the filing date $(-60,-2)$, the average CAAR is $-38.18 \%$. The Patell Z-value is 12.201 and is significant at the 0.1 percent level. Similarly, for the period $(-30,-2)$ and $(-1,0)$, the average CAARs are -39.86 percent and -20.35 percent, respectively, while both are significant at the 0.1 percent level. This test determines whether the abnormal stock returns equal zero, assuming cross-sectional independence. From this, we can conclude that there is ample loss of returns at stake, thus creating a strong motivation for insider trading.

Table 3: CAAR of Bankrupt Firms and Their Matched Control Firms

\begin{tabular}{cccc}
\hline \multicolumn{4}{c}{ Panel A: Bankrupt firms } \\
\hline Days & $\mathrm{N}$ & CAAR & Patell Z \\
$(-60,-2)$ & 45 & $-38.18 \%$ & $-12.201^{* * *}$ \\
$(-30,-2)$ & 45 & $-39.86 \%$ & $-14.613^{* * *}$ \\
$(-1,0)$ & 43 & $-20.35 \%$ & $-23.317^{* * *}$ \\
\hline \multicolumn{4}{c}{ Panel B: Matched control firms } \\
\hline Days & $\mathrm{N}$ & CAAR & Patell Z \\
$(-60,-2)$ & 94 & $-2.80 \%$ & -0.997 \\
$(-30,-2)$ & 94 & $-1.70 \%$ & -1.075 \\
$(-1,0)$ & 94 & $-1.24 \%$ & $-2.143^{*}$ \\
\hline
\end{tabular}

The Patell z-test examines whether abnormal stock return equals zero assuming cross sectional independence. The symbol *and $* * *$ denotes statistical significance at the 0.10 and 0.001 levels respectively using a 1 -tail test.

14 Note that the number of firms used in estimating the CAR is smaller than 129 sample bankrupt firms. This is so due to the fact that many firms stopped trading their shares some time prior to the bankruptcy filing, hence, they lack data to calculate the CAR. 
Panel B of Table 3 shows the average CAAR of the control firms over the same period used for their matching bankrupt firms. We are interested in the average CAAR values to establish that the control firms are not going through similar financial distress or some other events that will cause abnormal returns. We find that for the three time periods (-60, -2 days), (-30, -2 days), the average CAARs are -2.80 percent, -1.70 percent, and -1.24 percent, respectively, and only the period $(-1,0$ days) CAAR is significant at the 5 percent level of significance. Figure 1 shows the CAAR over the 60 days prior to the filing date for both the samples. The matched control firms' CAAR does not show any significant movement compared to that of the bankrupt firms. This dispels the possibility raised by Seyhun and Bradley (1997) that using control firms from the same industry may produce firms with similar problems like financial distress.

Figure 1: Bankrupt Firms and Their Matched Control Firms' CAAR for a Period of Two Months Prior to Filing for Bankruptcy

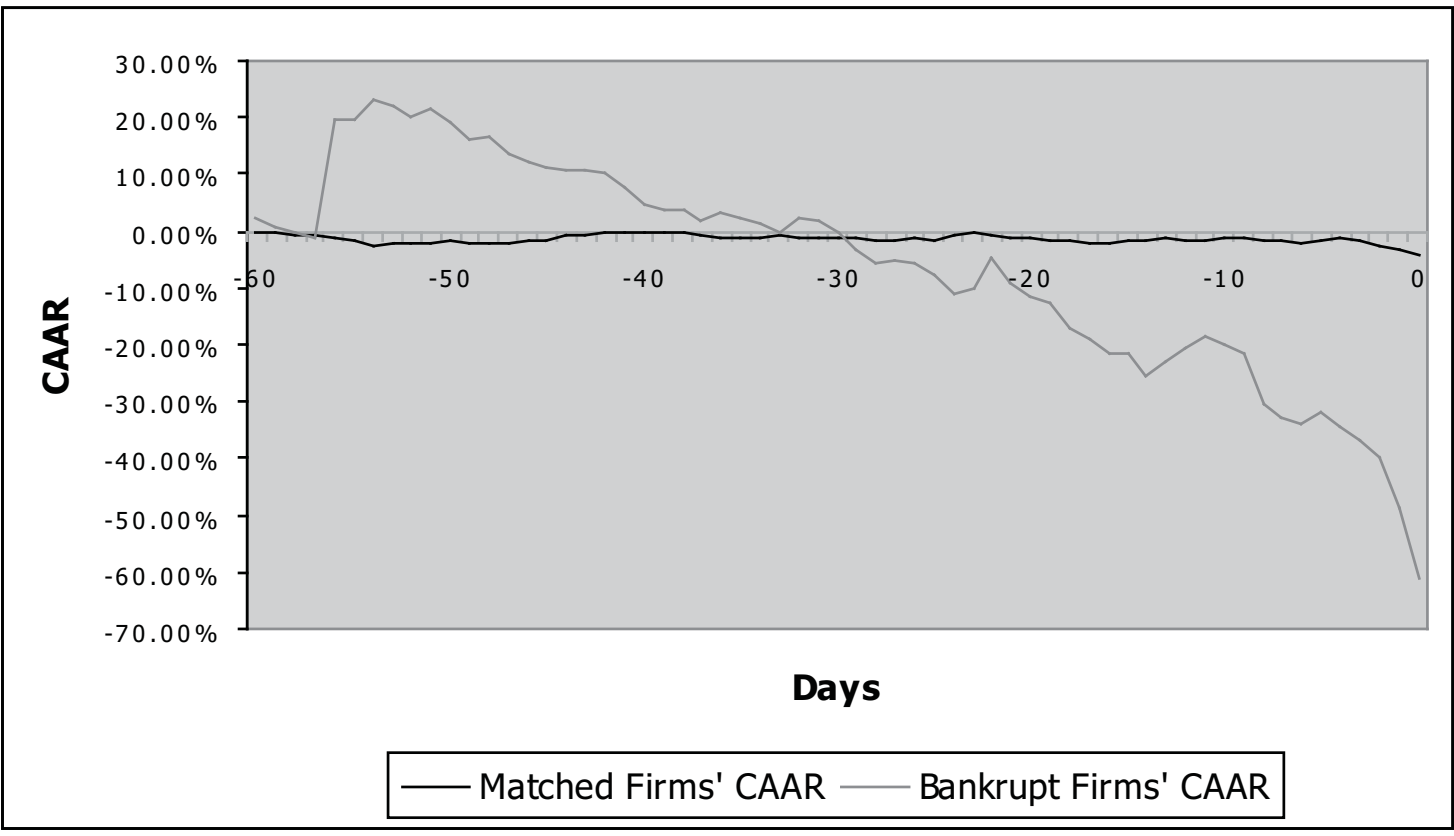

As previously mentioned, we compared the bankrupt firms to matched control firms in order to evaluate the extent of insider trading. Table 4 provides the descriptive statistics on trading volume in millions of dollars. We categorized firms into three categories:

1. positive net purchase (i.e., firm purchased more dollars worth of shares than they have sold);

2. negative net purchase;

3. zero net purchase (essentially, these are firms with no trading activity).

Data on Panel A is based on two years of insider trading data of both the bankruptcy and control firms. The two-year time span starts from two years prior to the date of the bankruptcy, and the same time span is used for the corresponding control firm. Similarly, data on Panel B and C is based on quarterly and monthly 
data, respectively, prior to the bankruptcy. If the insiders use their private information about future bankruptcy, they would sell more than they would purchase, and we would expect more firms categorized as the negative net purchase firms. However, in Panel A, we observed that in the bankruptcy sample, only 58 of the 129 firms were negative net purchase firms, which is roughly equal to the number of positive net purchase firms. In the control sample, negative net purchase firms are almost thrice in number compared to the positive net purchase firms. Over a shorter period of time, as shown in Panels B and C, the number of firms with negative net purchase declined sharply.

Table 4: Descriptive Statistics of Trading Volume over Different Time Horizons Prior to the Filing Date for Bankruptcy

Panel A: Net purchases of firms for two years prior to bankruptcy filing date

\begin{tabular}{|c|c|c|c|c|c|c|c|c|}
\hline \multirow{2}{*}{\multicolumn{2}{|c|}{ (In million dollars) }} & \multicolumn{3}{|c|}{ Positive net purchase } & \multicolumn{3}{|c|}{ Negative net purchase } & \multirow[t]{2}{*}{ Zero } \\
\hline & & Mean & Median & SD & Mean & Median & SD & \\
\hline \multirow{4}{*}{ 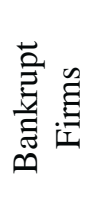 } & Purchase & 8.81 & 1.21 & 20.69 & 2.34 & 0.18 & 7.33 & \\
\hline & Sale & 1.73 & 0.09 & 6.31 & 77.99 & 8.12 & 188.86 & \\
\hline & Net purchase & 7.08 & 0.95 & 16.51 & -75.65 & -6.47 & 189.21 & \\
\hline & $\mathrm{N}$ & & 55 & & & 58 & & 16 \\
\hline \multirow{4}{*}{$\begin{array}{l}\vec{d} \\
\frac{d}{0} \\
\text { 节 }\end{array}$} & Purchase & 31.78 & 2.88 & 106.99 & 3.89 & 0.20 & 27.83 & \\
\hline & Sale & 4.39 & 0.18 & 12.08 & 80.51 & 11.67 & 224.76 & \\
\hline & Net purchase & 27.39 & 1.95 & 96.59 & -76.62 & -11.09 & 215.06 & \\
\hline & $\mathrm{N}$ & & 33 & & & 83 & & 13 \\
\hline
\end{tabular}

Panel B: Net purchases of firms for one quarter prior to bankruptcy filing date

\begin{tabular}{|c|c|c|c|c|c|c|c|c|}
\hline \multirow{2}{*}{\multicolumn{2}{|c|}{ (In million dollars) }} & \multicolumn{3}{|c|}{ Positive net purchase } & \multicolumn{3}{|c|}{ Negative net purchase } & \multirow[t]{2}{*}{ zero } \\
\hline & & Mean & Median & $\mathrm{SD}$ & Mean & Median & SD & \\
\hline \multirow{4}{*}{ 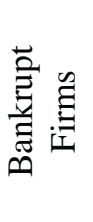 } & Purchase & 2.32 & 0.11 & 4.42 & 0.05 & 0.00 & 0.22 & \\
\hline & Sale & 0.97 & 0.00 & 2.84 & 1.72 & 0.23 & 3.34 & \\
\hline & Net purchase & 1.35 & 0.11 & 2.41 & -1.67 & -0.23 & 3.33 & \\
\hline & $\mathrm{N}$ & & 15 & & & 24 & & 90 \\
\hline \multirow{4}{*}{ 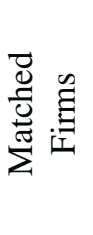 } & Purchase & 1.77 & 0.16 & 3.81 & 0.01 & 0.00 & 0.03 & \\
\hline & Sale & 0.05 & 0.00 & 0.16 & 15.93 & 1.45 & 63.34 & \\
\hline & Net purchase & 1.72 & 0.15 & 3.69 & -15.92 & -1.45 & 63.34 & \\
\hline & $\mathrm{N}$ & & 22 & & & 51 & & 56 \\
\hline
\end{tabular}

Panel C: Net purchases of firms for one month prior to bankruptcy filing date

\begin{tabular}{|c|c|c|c|c|c|c|c|c|}
\hline \multirow{2}{*}{\multicolumn{2}{|c|}{ (In million dollars) }} & \multicolumn{3}{|c|}{ Positive net purchase } & \multicolumn{3}{|c|}{ Negative net purchase } & Zero \\
\hline & & Mean & Median & SD & Mean & Median & SD & \\
\hline \multirow{4}{*}{ 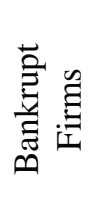 } & Purchase & 1.06 & 0.56 & 1.57 & 0.00 & 0.00 & 0.00 & \\
\hline & Sale & 0.05 & 0.00 & 0.13 & 1.32 & 0.13 & 3.13 & \\
\hline & Net purchase & 1.01 & 0.43 & 1.57 & -1.32 & -0.13 & 3.13 & \\
\hline & $\mathrm{N}$ & & 6 & & & 10 & & 113 \\
\hline
\end{tabular}


(continued)

\begin{tabular}{|c|c|c|c|c|c|c|c|c|}
\hline \multirow{4}{*}{ 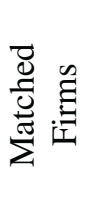 } & Purchase & 0.48 & 0.06 & 0.78 & 0.01 & 0.00 & 0.02 & \\
\hline & Sale & 0.00 & 0.00 & 0.01 & 5.34 & 0.76 & 12.50 & \\
\hline & Net purchase & 0.48 & 0.05 & 0.79 & -5.33 & -0.76 & 12.50 & \\
\hline & $\mathrm{N}$ & & 10 & & & 29 & & 90 \\
\hline
\end{tabular}

A closer inspection of the two samples had revealed that all statistics in the negative net purchase category are larger in size for the control firms. Similar results were found for the positive net purchase firm. Hence, the statistics reported in Table 4 suggest that the insiders of the bankrupt firms as a whole do not sell or buy more than other firms. Also, insiders of a larger number of bankrupt firms stopped trading as the period for bankruptcy filing approaches.

One may argue that some insiders of the bankrupt firms do sell more shares, but the dollar value is lower because of lower stock prices. However, the use of private information would imply that insiders should have sold the shares before the price declined. For instance, the CEO of Warnaco Group Inc., one of the bankrupt firms in our sample, sold approximately 1 million shares for $\$ 12.4$ million 18 months before the filing date, buying back these shares for $\$ 3$ million, 12 months later (6 months before bankruptcy), ultimately netting $\$ 9.4$ million. We do not know the real reason of these trades, yet, it raises questions about the use of private information.

Table 5: Trading Volume

This table presents the summary statistics of the trading volume along with $t$-test for mean equality and Wilcoxon signed rank test for the equality of the median. If the test statistics take a negative value that implies the bankrupt firms' trading volume is lower than that of their matched control. The last two columns present the percentage of banks that have zero insiders trading (in Panel A only purchase, and in Panel $\mathrm{B}$ only sales). Note that since the median data is always zero, it is not presented here.

Panel A: Purchase volume (in million dollars)

\begin{tabular}{|c|c|c|c|c|c|c|c|c|}
\hline \multirow[b]{2}{*}{ Quarter } & \multicolumn{2}{|c|}{ Bankrupt firms } & \multicolumn{2}{|c|}{$\begin{array}{l}\text { Matched } \\
\text { samples }\end{array}$} & \multicolumn{2}{|c|}{ Statistics } & \multicolumn{2}{|c|}{$\%$ of zeros } \\
\hline & Mean & S.D. & Mean & S.D. & t-test & Wilcoxon Z & Target & Matched \\
\hline-1 & 0.28 & 1.64 & 0.31 & 1.68 & -0.127 & $-2.025 * *$ & 86.05 & 75.19 \\
\hline-2 & 0.64 & 4.98 & 0.66 & 4.20 & -0.030 & -1.135 & 79.84 & 70.54 \\
\hline-3 & 0.95 & 6.20 & 0.91 & 6.19 & 0.057 & 1.489 & 69.77 & 76.74 \\
\hline-4 & 0.34 & 1.65 & 0.26 & 1.42 & 0.390 & 0.227 & 68.99 & 72.87 \\
\hline-5 & 0.80 & 5.23 & 0.89 & 5.34 & -0.143 & 0.267 & 65.89 & 70.54 \\
\hline-6 & 1.09 & 5.73 & 6.87 & 58.40 & -1.119 & -0.273 & 70.54 & 69.77 \\
\hline-7 & 0.54 & 2.95 & 0.60 & 3.02 & -0.151 & 1.211 & 53.49 & 68.99 \\
\hline-8 & 0.17 & 0.54 & 0.13 & 0.62 & 0.488 & 0.614 & 68.22 & 68.22 \\
\hline
\end{tabular}


Panel B: Sales volume (in million dollars)

\begin{tabular}{ccccccccc}
\hline & \multicolumn{3}{c}{ Bankrupt firms } & \multicolumn{2}{c}{$\begin{array}{c}\text { Matched } \\
\text { samples }\end{array}$} & \multicolumn{2}{c}{ Statistics } & \multicolumn{2}{c}{$\%$ of zeros } \\
\hline Quarter & Mean & S.D. & Mean & S.D. & t-test & Wilcoxon Z & Target & Matched \\
\hline-1 & 0.43 & 1.83 & 6.31 & 40.40 & $-1.651^{*}$ & $-3.563^{* * *}$ & 76.74 & 57.36 \\
-2 & 1.04 & 5.23 & 6.16 & 32.70 & $-1.752^{*}$ & $-3.484^{* * *}$ & 80.62 & 62.02 \\
-3 & 2.42 & 14.90 & 10.90 & 86.60 & -1.093 & $-3.668^{* * *}$ & 81.4 & 59.69 \\
-4 & 1.79 & 10.80 & 13.10 & 83.90 & -1.512 & $-3.703^{* * *}$ & 72.09 & 51.94 \\
-5 & 3.65 & 17.20 & 4.22 & 16.10 & -0.288 & -1.485 & 72.87 & 62.02 \\
-6 & 3.19 & 14.60 & 3.69 & 19.00 & -0.414 & $-2.240^{* *}$ & 72.09 & 58.91 \\
-7 & 14.00 & 86.90 & 2.99 & 9.59 & 1.431 & -0.780 & 63.57 & 60.47 \\
-8 & 9.34 & 46.70 & 5.59 & 30.80 & 0.783 & -0.467 & 62.79 & 55.81 \\
\hline
\end{tabular}

Panel C: Net purchase volume (in million dollars)

\begin{tabular}{ccccccccc}
\hline & \multicolumn{3}{c}{ Bankrupt firms } & \multicolumn{2}{c}{$\begin{array}{c}\text { Matched } \\
\text { samples }\end{array}$} & \multicolumn{2}{c}{ Statistics } & \multicolumn{2}{c}{$\%$ of zeros } \\
\hline Quarter & Mean & S.D. & Mean & S.D. & t-test & Wilcoxon Z & Target & Matched \\
\hline-1 & -0.15 & 1.83 & -6.00 & 40.40 & 1.641 & $2.520^{* *}$ & 69.77 & 43.41 \\
-2 & -0.40 & 7.28 & -5.51 & 33.10 & $1.710^{*}$ & $2.592^{* * *}$ & 64.34 & 44.19 \\
-3 & -1.46 & 14.80 & -9.99 & 86.90 & 1.095 & $3.562^{* * *}$ & 58.91 & 45.74 \\
-4 & -1.45 & 10.90 & -12.80 & 83.90 & 1.522 & $3.365^{* * *}$ & 50.39 & 41.86 \\
-5 & -2.85 & 18.10 & -3.33 & 17.20 & 0.230 & 1.310 & 50.39 & 44.19 \\
-6 & -2.10 & 15.80 & 3.18 & 57.90 & -1.054 & $1.703^{*}$ & 52.71 & 41.86 \\
-7 & -13.40 & 87.00 & -2.39 & 10.10 & -1.436 & 1.162 & 37.21 & 40.31 \\
-8 & -9.17 & 46.70 & -5.45 & 30.80 & -0.776 & 0.859 & 41.86 & 40.31 \\
\hline
\end{tabular}

The symbols $* * *$, and $* * *$ denote statistical significance at the $0.10,0.05$, and 0.01 levels, respectively, using a 2-tail test.

We performed the Wilcoxon signed-rank test as well as $t$-test on two insidertrading measures: trading volume in dollars and the number of insiders. The results are presented in Tables 5 and 6 . Each of the insider trading measures is documented for purchases (Panel A), sales (Panel B), and net purchases (Panel C) for the 8 quarters prior to the bankruptcy. If we are to find profitable or loss avoiding insider trading by the bankrupt firm, the test statistics should have negative signs for purchases and net purchases, and positive signs for sales of both insider trading measures. ${ }^{15}$ However, only few statistics show the sign consistent with insider trading, and they are not even significant at any accepted level. On the contrary, any significant statistics that the table presents points to no insider trading. Note that for both insider-trading measures (i.e., Tables 5 and 6), insider sales (i.e., Panel B) and $\mathrm{z}$-statistics are significant and negative for the quarters -4 to -1 . This implies that insiders of control firms are significantly selling more than that of the bankrupt

15 The test statistics are computed as (Bankruptcy firms quarter ${ }_{i}-$ control firms quarter ${ }_{i}$, where $i=-8,-7, \ldots,-1)$. 
Table 6: Number of Insiders Buying or Selling

This table presents the summary statistics of the number of insiders buying or selling along with $t$-test for mean equality and Wilcoxon signed rank test of the equality for the median. If the test statistics take a negative value that implies the bankrupt firms' number of insiders is lower than that of their matched control. The last two columns present the percentage of banks that have more than one insiders trading (in Panel A only purchase, and in Panel B only sales). Note that since the median data is always zero, it is not presented here.

\section{Panel A: Number of insiders buying}

\begin{tabular}{|c|c|c|c|c|c|c|c|c|}
\hline \multirow[b]{2}{*}{ Quarter } & \multicolumn{2}{|c|}{$\begin{array}{l}\text { Bankrupt } \\
\text { firms }\end{array}$} & \multicolumn{2}{|c|}{ Matched samples } & \multicolumn{2}{|c|}{ Statistics } & \multicolumn{2}{|c|}{$\%$ of $>2$ insiders } \\
\hline & Mean & S.D. & Mean & S.D. & t-test & Wilcoxon Z & Target & Matched \\
\hline-1 & 0.32 & 1.04 & 0.60 & 1.61 & $-1.718 *$ & $-2.125 * *$ & 6.20 & 11.63 \\
\hline-2 & 0.40 & 1.11 & 0.70 & 2.28 & -1.556 & $-1.820 *$ & 6.20 & 10.85 \\
\hline-3 & 0.70 & 1.39 & 0.78 & 3.33 & -0.240 & 1.172 & 16.28 & 12.40 \\
\hline-4 & 0.81 & 1.57 & 0.67 & 3.25 & 0.410 & 1.127 & 19.38 & 9.30 \\
\hline-5 & 0.95 & 1.92 & 0.69 & 1.51 & 1.163 & 1.017 & 18.60 & 16.28 \\
\hline-6 & 0.72 & 1.52 & 0.64 & 1.54 & 0.409 & 0.734 & 16.28 & 10.85 \\
\hline-7 & 1.08 & 1.71 & 0.71 & 1.44 & $1.920 *$ & $2.363 * *$ & 22.48 & 16.28 \\
\hline-8 & 0.98 & 2.01 & 0.66 & 1.66 & 1.464 & 1.035 & 20.93 & 13.95 \\
\hline
\end{tabular}

Panel B: Number of insiders selling

\begin{tabular}{|c|c|c|c|c|c|c|c|c|}
\hline \multirow[b]{2}{*}{ Quarter } & \multicolumn{2}{|c|}{ Bankrupt firms } & \multicolumn{2}{|c|}{$\begin{array}{c}\text { Matched } \\
\text { samples }\end{array}$} & \multicolumn{2}{|c|}{ Statistics } & \multicolumn{2}{|c|}{$\%$ of $>2$ insiders } \\
\hline & Mean & S.D. & Mean & S.D. & t-test & Wilcoxon Z & Target & Matched \\
\hline-1 & 0.33 & 0.70 & 1.14 & 1.88 & $-4.632 * * *$ & $-3.976 * * *$ & 6.98 & 27.13 \\
\hline-2 & 0.38 & 1.09 & 0.92 & 1.60 & $-3.339 * * *$ & $-3.561 * * *$ & 6.98 & 20.16 \\
\hline-3 & 0.35 & 1.24 & 1.36 & 2.71 & $-4.001 * * *$ & $-4.691 * * *$ & 5.43 & 27.13 \\
\hline-4 & 0.53 & 1.36 & 1.22 & 1.98 & $-3.032 * * *$ & $-3.397 * * *$ & 10.08 & 24.03 \\
\hline-5 & 0.71 & 1.76 & 1.03 & 2.11 & -1.269 & -1.344 & 14.73 & 20.93 \\
\hline-6 & 0.71 & 1.58 & 1.25 & 2.14 & $-2.591 * *$ & $-2.484 * * *$ & 14.73 & 27.13 \\
\hline-7 & 1.01 & 2.44 & 1.07 & 2.35 & -0.209 & -0.361 & 16.28 & 21.71 \\
\hline-8 & 1.30 & 2.99 & 1.15 & 1.90 & 0.526 & -0.583 & 19.38 & 24.81 \\
\hline
\end{tabular}

Panel C: Net number of insiders buying

\begin{tabular}{|c|c|c|c|c|c|c|c|c|}
\hline \multirow[b]{2}{*}{ Quarter } & \multicolumn{2}{|c|}{$\begin{array}{l}\text { Bankrupt } \\
\text { firms }\end{array}$} & \multicolumn{2}{|c|}{$\begin{array}{l}\text { Matched } \\
\text { samples }\end{array}$} & \multicolumn{2}{|c|}{ Statistics } & \multicolumn{2}{|c|}{$\%$ of $>2$ insiders } \\
\hline & Mean & S.D. & Mean & S.D. & t-test & Wilcoxon Z & Target & Matched \\
\hline-1 & -0.02 & 1.12 & -0.54 & 2.60 & $2.052 * *$ & $2.109 * *$ & 11.63 & 37.21 \\
\hline-2 & 0.02 & 1.56 & -0.22 & 2.89 & 0.938 & 1.281 & 12.40 & 29.46 \\
\hline-3 & 0.35 & 1.85 & -0.59 & 3.93 & $2.412 * *$ & $4.208 * * *$ & 20.93 & 35.66 \\
\hline-4 & 0.27 & 2.09 & -0.54 & 3.51 & $2.217 * *$ & $3.986 * * *$ & 27.13 & 31.78 \\
\hline-5 & 0.23 & 2.66 & -0.34 & 2.61 & $1.724 *$ & $2.305 * *$ & 31.01 & 34.11 \\
\hline-6 & 0.02 & 2.27 & -0.60 & 2.50 & $2.195 * *$ & $2.371 * *$ & 28.68 & 34.88 \\
\hline-7 & 0.07 & 3.10 & -0.36 & 2.85 & 1.181 & $1.956 *$ & 35.66 & 35.66 \\
\hline-8 & -0.32 & 3.74 & -0.49 & 2.54 & 0.458 & 1.485 & 36.43 & 33.33 \\
\hline
\end{tabular}

The symbols ***, and $* * *$ denote statistical significance at the $0.10,0.05$, and 0.01 levels, respectively, using a 2-tail test. 
firms. Similarly, z-statistics reported in Panel $\mathrm{C}$ of Table 5 and 6 confirms that insiders of control firms are either selling more or buying less than that of bankrupt firms.

Table 5 shows that in the quarter prior to bankruptcy, less than 25 percent (15 percent) of the bankrupt firms have insider selling (purchasing). Similarly, Table 6 shows that in the same quarter, less than 7 percent of the bankrupt firms have more than two insiders selling, whereas for the corresponding control firms, this figure is more than $25 \%$. Hence, contrary to popular belief, insiders of large public firms do not engage in trading based upon private information for private gain or loss avoidance. It does not mean that there exists no insider trading, but rather, insider trading is more of an exception than a rule.

Table 7: Wilcoxon Signed-Rank Test Base on Monthly Data

This table presents statistics for Wilcoxon signed rank test of the equality for the median. If the test statistics take a negative value that implies the bankrupt firms' trading volume or number of insiders, whichever is appropriate, is lower than that of their matched control.

\begin{tabular}{ccccccc}
\hline & \multicolumn{3}{c}{$Z$-statistics for trading volume in dollars } & \multicolumn{2}{c}{$Z$-statistics for number of insiders } \\
\hline Month & Purchase & Sale & Net purchase & Purchase & Sale & Net purchase \\
\hline-1 & -1.417 & $-3.391^{* * *}$ & $2.489^{* *}$ & -1.411 & $-3.478^{* * *}$ & $2.353^{* *}$ \\
-2 & -1.297 & $-2.695^{* * *}$ & $1.679^{*}$ & -1.232 & $-2.553^{* *}$ & 1.152 \\
-3 & -0.469 & $-2.730^{* * *}$ & $2.502^{* *}$ & -0.793 & $-2.634^{* * *}$ & $2.060^{* *}$ \\
-4 & -0.704 & $-2.350^{* *}$ & 1.538 & -1.240 & $-1.896^{*}$ & 0.510 \\
-5 & 0.451 & $-2.695^{* * *}$ & $2.793^{*}$ & 0.225 & $-2.636^{* * *}$ & $2.374 * *$ \\
-6 & -0.695 & $-2.738^{* * *}$ & 1.537 & -1.008 & $-2.329 * *$ & 1.092 \\
-7 & 0.487 & -1.496 & 1.448 & 0.725 & -1.627 & 1.570 \\
-8 & 1.739 & $-2.479 * *$ & $2.568^{* *}$ & 1.323 & $-2.802^{* * *}$ & $3.159 * * *$ \\
-9 & 1.136 & $-3.995^{* * *}$ & $3.612^{* * *}$ & 1.076 & $-4.035^{* * *}$ & $3.558^{* * *}$ \\
-10 & -0.177 & $-2.715^{* * *}$ & $1.807 *$ & 0.305 & $-2.827 * * *$ & $2.933^{* * *}$ \\
-11 & 0.709 & $-2.560^{* *}$ & $2.601 * * *$ & 1.041 & $-2.471^{* *}$ & $2.696^{* * *}$ \\
-12 & 1.206 & $-2.895^{* * *}$ & $3.288^{* *}$ & 1.361 & $-2.647 * * *$ & $3.191^{* * *}$ \\
\hline
\end{tabular}

The symbols $* * *$, and $* * *$ denote statistical significance at the $0.10,0.05$, and 0.01 levels, respectively, using a 2-tail test.

Since insider-trading activity is very infrequent, we used quarterly data for the previous analysis. For a robustness check, we reported test statistics in Table 7 with similar results based on monthly data. In fact, we conducted a battery of robustness checks. For instance, we increased the sample size by lowering the asset size cut off point, as well as using an alternative control group that matched firms based on market capitalization. All cases were essentially the same. We also checked for insider trading in subgroups. For example, we examined for any discernible differences between the 50 firms that "either filed for bankruptcy because of fraud or 
did not survive the bankruptcy process". However, we did not find any differences in the insider trading behavior between these two groups.

Our results are similar to those of Loderer and Sheehan (1989). Seyhun and Bradley (1997) had criticized Loderer and Sheehan's (1989) sample size and data, arguing that they were unable to capture all insiders trading. Seyhun and Bradley (1997) had argued that Loderer and Sheehan (1989) used proxy statements to collect the insider trading data, and this data selection technique yields a sample of mostly large exchange listed firms. We, however, intentionally picked large firms in our sample to observe the behavior of the insiders during the last twelve years as there are many cases of large firms filing for bankruptcy amid a torrent of bad corporate governance practice allegations.

Ma's (2001) results are similar to ours. He had found that there is significantly less insider purchase, especially prior to the bankruptcy, yet, no significant insider selling was present. Ma had used a relatively small sample of 89 during the period of 1982 through 1990 for firms that filed for Chapter 11 bankruptcy.

The obvious question is whether the results presented in Tables 5 and 6 are expected or not. One of the arguments based on Chapter 11 bankruptcy process is the favoring of insiders, while the other is based on a good corporate governance and legal system. We realize that the majority of the Chapter 11 filings are self-initiated (i.e., debtor initiated). Also, filing for Chapter 11 helps managers to restructure their firm while keeping their job. Therefore, insiders may perceive that either saving their job or future employability outweighs any potential benefit from insider trading. However, there exists a considerable amount of controversy surrounding the state of corporate governance in the U.S.

Holmstrom and Kaplan (2003) had provided evidence that U.S. corporate governance is in much better shape than the rest of the world. Also, as evidenced by Bettis et al. (2000), most U.S. firms have instituted mechanisms restricting insider trading. Moreover, current developments toward more transparent and speedy reporting instituted by the Sarbanes-Oxley Act of 2002 and harsher penalty imposed by the legal system on corporate fraud and insider trading, severely deters any large insider trading.

\section{Conclusion}

In this paper, we examined the extent of insider trading for 129 large Chapter 11 bankruptcy filings firms for the twelve-year period of 1995-2006. Although, these firms suffered a significant reduction of their stock prices over the period as documented by significant negative CARs, the insiders of these firms are found not to engage in trading that is significantly different from firms of similar size and of similar industry in most cases.

In some cases where the trading is significantly different, it shows that insiders of similar non-bankrupt firms are either selling more or buying less than in the bankrupt firms. There are, however, incidences of insider trading as reported in the media (these are the exception, rather than common practice). There are several possible explanations as to why this is so. One reason is that managers of these 
large firms find it profitable to file for Chapter 11 bankruptcy to save their jobs. Any insider trading activity would put their current job or future potential jobs at risk. Other reasons are that there is a good corporate governance and legal system in place that actively deters insider trading.

Author statement: Tareque Nasser is the corresponding author at the University of Alabama, 200 Alston Hall, Box 870224,AL 35487, United States of America. (1)205-348-7592; Fax: (1)-205-348-0590; Email: tnasser@cba.ua.edu. Benton Gup's affiliation is with the Birmingham campus of the same university.

\section{References}

Agrawal, Anup, and Jeffery F. Jaffe, (1995). Does Section 16b deter insider trading by target mangers? Journal of Financial Economics 39, 295-319.

Ball, Ray and Phillip Brown, (1968). An empirical evaluation of accounting income numbers, Journal of Accounting Research 6, 159-178.

Beams, Joseph D., Robert M. Brown and Larry N. Killoug, (2003). An experiment testing the determinants of non-compliance with insider trading laws, Journal of Business Ethics 45, 309-323.

Becht, Marco, Patrick Bolton, and Alisa Roell, (2003). Corporate governance and control, in G. M. Constantinides, M. Harris and R. Stulz, ed.: Handbook of Economics of Finance, Elsevier B.V.

Betker, B. L, (1995). Management's incentives, equity's bargaining power, and deviation from absolute priority in Chapter 11 bankruptcies, Journal of Business 68, 161-183.

Bettis, J.C., J.L Coles, and M.L. Lemmon, (2000). Corporate policies restricting trading by insiders, Journal of Financial Economics 57, 191-220.

Bettis, J.C., W. A. Duncan, and W. K. Harmon, (1998). The effectiveness of insider trading regulations, Journal of Applied Business Research 14, 53-70.

Bradley, Michael and Michael Rosenzweig, (1992). The untenable case for Chapter 11, Yale Law Journal 101, 1043-1095.

Bris, Arturo, (2005). Do insider trading laws work? European Financial Management 11, 267-312.

Carlton, Denis W. and Daniel R. Fischel, (1983). The regulation of insider trading, Stanford Law Review 35, 857-895.

DeMarzo, Peter M., Michael J. Fishman, and Kathleen M. Hagerty, (1998). The optimal enforcement of insider trading regulations, Journal of Political Economy 106, 602-632.

Dye, Ronald A, (1984). Insider trading and incentives, Journal of Business 57, 295 313.

Easterbrook, Frank, 1981, Insider trading, secret agents, evidentiary privileges, and the production of information, Supreme Court Review, 309-365.

Elliot, John, Dale Morse, and Gordon Richardson, (1984). The association between insider trading and information announcements, Rand Journal of Economics $15,521-536$. 
Fama, Eugene, Lawrence Fisher, Michael Jensen and Richard Roll, (1969). The adjustment of stock prices of new information, International Economic Review 10, 1-21.

Finnerty, Joseph E., (1976). Insiders' activity and inside information: A multivariate analysis, Journal of Financial and Quantitative Analysis 11, 205-215.

Fischer, Paul E., (1992). Optimal contracting and insider trading restrictions, Journal of Finance 47, 673-694.

Gosnell, T., A. Keown, and J. Pinkerton, (1992). Bankruptcy and insider trading: Differences between exchange-listed and OTC firms, Journal of Finance 47, 349-362.

Gup, B. E. and P. Agrrawal, (1996). The product life cycle: A paradigm for understanding financial management, Financial Practice and Education 6, 41-48.

Harlow, W. V. and John S. Howe, (1993). Leverage Buyouts and insider nontrading, Financial Management 22, 109-118.

Holmstrom, Bengt, and Steven N. Kaplan, (2003). The state of U.S. corporate governance: What's right and what's wrong? Working Paper, National Bureau of Economic Research.

Iqbal, Z. and S. Shetty, 2002, Insider trading and stock market perception of bankruptcy, Journal of Economics and Business 54, 525-535.

Irani, Afshad J., (2003). Management earning forecast bias and insider trading: Comparison of distressed and non-distressed firms, Journal of Business \& Economic Studies 9, 12-25.

Jaffe, J. F., (1974). Special information and insider trading, Journal of Business 47, 410-428.

Karpoff, Jonathan M., and Daniel Lee, (1991). Insider trading before new issue announcements, Financial Management 20, 18-26.

Lakonishok, J. and I. Lee, (2001). Are insider trades informative? Review of Financial Studies 14, 79-111.

Lin, J., and J. Howe, (1990). Insider trading in the OTC market, Journal of Finance 45, 1273-1284.

Loderer, C. F. and D. P. Sheehan, (1989). Corporate bankruptcy and manager's selfserving behavior, Journal of Finance 44, 1059-1075.

LoPucki, Lynn M., and William C. Whitford, (1993). Corporate governance in the bankruptcy reorganization of large, publicly held companies, University of Pennsylvania Law Review 141, 669-800.

Lynn M. LoPucki's Bankruptcy Research Database (WebBRD), http://lopucki.law. ucla.edu/index.htm.

Lorie, James H. and Victor Niederhoffer, (1968). Predictive and statistical properties of insider trading, Journal of Law and Economics 11, 35-51.

Ma, Y., (2001). Insider trading behavior prior to Chapter 11 bankruptcy announcements, Journal of Business Research 54, 63-70.

Penman, S., (1982). Insider trading and the dissemination of firm's forecast information, Journal of Business 55, 479-503.

Penman, S., (1985). A comparison of the information content of insider trading and management earning forecasts, Journal of Financial and Quantitative Analysis 20, 1-17. 
Rozeff, M. S. and M. A. Zaman, (1988). Marker efficiency and insider trading: New evidence, Journal of Business 61, 25-44.

Seyhun, N., (1986). Insider's profits, costs of trading, and market efficiency, Journal of Financial Economics 16, 189-212.

Seyhun, N., (1992)., The effectiveness of insider trading sanctions, Journal of Law and Economics 35, 149-182.

Seyhun, N. and M. Bradley, (1997). Corporate bankruptcy and insider trading, Journal of Business 70, 189-216.

Shin, Jhinyoun, (1996). The optimal regulation of insider trading, Journal of Financial Intermediation 5, 49-73.

White, Michelle J., (1989). The corporate bankruptcy decision, Journal of Economic Perspective 3, 129-151. 


\section{Appendix A: List of $n=129$ sample bankrupt firms}

The asset size in millions of dollars as reported in the Compustat two years prior to the bankruptcy filing year.

\begin{tabular}{|c|c|c|}
\hline Name & Bankruptcy filing date & $\begin{array}{c}\text { Asset size } \\
\text { (In million dollars) } \\
\end{array}$ \\
\hline WORLDCOM, INC. & July 21, 2002 & 98,903 \\
\hline CONSECO, INC. & December 18, 2002 & 58,589 \\
\hline REFCO FINANCE INC. & October 17, 2005 & 48,765 \\
\hline ENRON CORP. & December 2, 2001 & 33,381 \\
\hline GLOBAL CROSSING LTD. & January 28, 2002 & 30,185 \\
\hline PACIFIC GAS \& ELECTRIC CO. & April 6, 2001 & 29,715 \\
\hline CALPINE CORP. & December 20, 2005 & 27,304 \\
\hline DELTA AIR LINES, INC. & September 14, 2005 & 26,356 \\
\hline UAL CORPORATION (UNITED AIRLINES) & December 9, 2002 & 24,355 \\
\hline MIRANT CORP. & July 14,2003 & 22,754 \\
\hline ADELPHIA COMMUNICATIONS CORP. & June 25,2002 & 21,499 \\
\hline DELPHI CORPORATION & October 8, 2005 & 20,904 \\
\hline KMART CORP. & January 22,2002 & 14,630 \\
\hline RELIANCE GROUP HOLDINGS, INC. & June 12, 2001 & 14,616 \\
\hline NORTHWEST AIRLINES CORPORATION & September 14, 2005 & 14,154 \\
\hline FINOVA GROUP, INC. & March 7, 2001 & 14,050 \\
\hline NTL, INC. & May 8, 2002 & 13,026 \\
\hline NRG ENERGY, INC. & May 14, 2003 & 12,895 \\
\hline PG\&E NATIONAL ENERGY GROUP & July 8, 2003 & 10,329 \\
\hline FEDERAL-MOGUL CORPORATION & October 1,2001 & 9,945 \\
\hline US AIRWAYS, INC. & August 11, 2002 & 9,127 \\
\hline AT HOME CORP & September 28, 2001 & 9,104 \\
\hline XO COMMUNICATIONS, INC. & June 17, 2002 & 9,085 \\
\hline DANA CORPORATION & March 3, 2006 & 9,019 \\
\hline COMDISCO, INC. & July 16, 2001 & 7,807 \\
\hline HOME HOLDINGS, INC. & January 15, 1998 & 7,593 \\
\hline MCLEODUSA, INC. & January 30, 2002 & 7,366 \\
\hline ARM FINANCIAL GROUP, INC. & December 20, 1999 & 7,138 \\
\hline ANC RENTAL CORP & November 13, 2001 & 6,350 \\
\hline BETHLEHEM STEEL CORP & October 15, 2001 & 5,536 \\
\hline INTEGRATED HEALTH SERVICES, INC. & February 2, 2000 & 5,393 \\
\hline LTV CORP. & December 29, 2000 & 5,324 \\
\hline OWENS CORNING & October 5, 2000 & 5,101 \\
\hline TRENWICK GROUP LTD. & August 20, 2003 & 4,929 \\
\hline GENUITY INC. & November 27, 2002 & 4,899 \\
\hline BUDGET GROUP INC. & July 29, 2002 & 4,520 \\
\hline
\end{tabular}




\begin{tabular}{|c|c|c|}
\hline PSINET & May 31,2001 & 4,492 \\
\hline LORAL SPACE \& COMMUNICATIONS LTD. & July 15,2003 & 4,390 \\
\hline ARMSTRONG WORLD INDUSTRIES, INC. & December 6, 2000 & 4,273 \\
\hline GLOBAL TELESYSTEMS, INC. & November 14, 2001 & 4,002 \\
\hline AMERCO & June 20,2003 & 3,773 \\
\hline FLEMING COMPANIES, INC. & April 1, 2003 & 3,655 \\
\hline IRIDIUM LLC & August 13, 1999 & 3,646 \\
\hline ASIA GLOBAL CROSSING, LTD. ${ }^{\wedge}$ & November 18, 2002 & 3,633 \\
\hline CHS ELECTRONICS, INC. ^ & April 4, 2000 & 3,572 \\
\hline SOLUTIA, INC. & December 17, 2003 & 3,408 \\
\hline KAISER ALUMINUM CORP. & February 12, 2002 & 3,343 \\
\hline COVANTA ENERGY CORP. & April 1, 2002 & 3,295 \\
\hline COLLINS \& AIKMAN & May 17,2005 & 3,191 \\
\hline FLAG TELECOM HOLDINGS, LTD & April 12, 2002 & 3,079 \\
\hline WINSTAR COMMUNICATIONS, INC. ^ & April 18, 2001 & 3,065 \\
\hline TOUCH AMERICA HOLDINGS INC $\wedge$ & June 19, 2003 & 3,059 \\
\hline SPECTRASITE HOLDINGS, INC. & November 15, 2002 & 3,054 \\
\hline MARINER POST-ACUTE NETWORK, INC. & January 18,2000 & 3,037 \\
\hline TOWER AUTOMOTIVE, INC. & February 2, 2005 & 2,846 \\
\hline PHILIP SERVICES CORP. * & June 25, 1999 & 2,823 \\
\hline WINN-DIXIE STORES, INC. & February 21, 2005 & 2,790 \\
\hline HAYES LEMMERZ INTERNATIONAL, INC. & December 5, 2001 & 2,777 \\
\hline USG CORP. & June 25, 2001 & 2,773 \\
\hline WARNACO GROUP INC. & June 11,2001 & 2,763 \\
\hline VIATEL INC. & May 2, 2001 & 2,704 \\
\hline ENCOMPASS SERVICES CORPORATION & November 19, 2002 & 2,700 \\
\hline NORTHWESTERN CORP. & September 14, 2003 & 2,617 \\
\hline CHIQUITA BRANDS INTERNATIONAL, INC. & November 28, 2001 & 2,596 \\
\hline SUN HEALTHCARE GROUP, INC. & October 14, 1999 & 2,579 \\
\hline NATIONAL STEEL CORP. ^ & March 6, 2002 & 2,565 \\
\hline W.R. GRACE \& COMPANY & April 2, 2001 & 2,493 \\
\hline FRUIT OF THE LOOM, INC. & December 29, 1999 & 2,483 \\
\hline LEAP WIRELESS INTERNATIONAL INC. & April 13, 2003 & 2,451 \\
\hline CONTIFINANCIAL CORP. ${ }^{\wedge}$ & May 17,2000 & 2,355 \\
\hline EXIDE TECHNOLOGIES & April 14, 2002 & 2,299 \\
\hline TRUMP HOTELS \& CASINO RESORTS INC. & November 21, 2004 & 2,196 \\
\hline TRANS WORLD AIRLINES, INC. ^ & January 10, 2001 & 2,137 \\
\hline $\begin{array}{l}\text { PEGASUS SATELLITE COMMUNICATIONS, } \\
\text { INC. ^ }\end{array}$ & June 2, 2004 & 2,111 \\
\hline $\mathrm{POLAROID} \mathrm{CORP}^{\wedge}$ & October 12, 2001 & 2,040 \\
\hline PEREGRINE SYSTEMS, INC. * & September 22, 2002 & 2,004 \\
\hline HIGHLANDS INSURANCE GROUP, INC. ^ & October 31, 2002 & 2,001 \\
\hline
\end{tabular}




\begin{tabular}{|c|c|c|}
\hline RCN CORPORATION & May 27, 2004 & 1,990 \\
\hline AMES DEPARTMENT STORES, INC. & August 20, 2001 & 1,975 \\
\hline SERVICE MERCHANDISE COMPANY, INC.^ & March 27, 1999 & 1,951 \\
\hline HEILIG-MEYERS COMPANY & August 16, 2000 & 1,948 \\
\hline LOEWS CINEPLEX ENTERTAINMENT CORP & February 15, 2001 & 1,907 \\
\hline SPIEGEL INC. & March 17, 2003 & 1,890 \\
\hline ADELPHIA BUSINESS SOLUTIONS, INC. * & March 27, 2002 & 1,889 \\
\hline BURLINGTON INDUSTRIES, INC. $* \wedge$ & November 15, 2001 & 1,876 \\
\hline AMF BOWLING, INC. & July 3, 2001 & 1,827 \\
\hline RSL COMMUNICATIONS, LTD. ${ }^{\wedge}$ & March 19, 2001 & 1,803 \\
\hline ALLEGIANCE TELECOM INC. ^^ & May 14, 2003 & 1,775 \\
\hline EXODUS COMMUNICATIONS, INC. ^ & September 26, 2001 & 1,743 \\
\hline AURORA FOODS INC. $* \wedge$ & December 8, 2003 & 1,723 \\
\hline UNICAPITAL CORPORATION ^ & December 11, 2000 & 1,670 \\
\hline HECHINGER COMPANY ^ & June 11,1999 & 1,668 \\
\hline VIASYSTEMS GROUP INC. & March 11, 2003 & 1,667 \\
\hline PILLOWTEX CORP. (2000) & November 14,2000 & 1,654 \\
\hline INTERSTATE BAKERIES CORPORATION & September 22, 2004 & 1,646 \\
\hline WORLD ACCESS, INC. ${ }^{\wedge}$ & April 24, 2001 & 1,630 \\
\hline ICG COMMUNICATIONS, INC. & November 14,2000 & 1,625 \\
\hline MAGELLAN HEALTH SERVICES INC. & October 1,2002 & 1,611 \\
\hline PAGING NETWORK, INC. & July 24,2000 & 1,581 \\
\hline PENN TRAFFIC CO & March 1, 1999 & 1,564 \\
\hline NATIONSRENT, INC. & December 17, 2001 & 1,559 \\
\hline BOSTON CHICKEN, INC. * & October 5, 1998 & 1,544 \\
\hline POLYMER GROUP, INC. & May 11, 2002 & 1,508 \\
\hline DVI INC. $\wedge$ & August 25, 2003 & 1,478 \\
\hline PINNACLE HOLDINGS, INC. & May 21, 2002 & 1,470 \\
\hline LODGIAN, INC. & December 20, 2001 & 1,424 \\
\hline ATLAS AIR WORLDWIDE HOLDINGS INC. & January 30, 2004 & 1,401 \\
\hline WESTPOINT STEVENS INC. & June 1, 2003 & 1,369 \\
\hline CRIIMI MAE INC. & October 5, 1998 & 1,367 \\
\hline GENTEK, INC. & October 11, 2002 & 1,351 \\
\hline PAYLESS CASHWAYS, INC. & July 21, 1997 & 1,344 \\
\hline $\begin{array}{l}\text { UNITED COMPANIES FINANCIAL } \\
\text { CORPORATION }^{\wedge}\end{array}$ & March 1, 1999 & 1,337 \\
\hline IT GROUP, INC. ^^ & January 16,2002 & 1,323 \\
\hline IMPERIAL SUGAR COMPANY & January 16, 2001 & 1,281 \\
\hline MORRISON KNUDSEN CORP. & June 25, 1996 & 1,273 \\
\hline ANCHOR GLASS CONTAINER CORP. & September 13, 1996 & 1,264 \\
\hline APW LTD. & May 16,2002 & 1,214 \\
\hline $\begin{array}{l}\text { WASHINGTON GROUP INTERNATIONAL, } \\
\text { INC. * }\end{array}$ & May 14,2001 & 1,196 \\
\hline
\end{tabular}




\begin{tabular}{|c|c|c|}
\hline $\begin{array}{l}\text { AMERICAN BUSINESS FINANCIAL } \\
\text { SERVICES, INC. }\end{array}$ & January 21, 2005 & 1,159 \\
\hline GST TELECOMMUNICATIONS, INC. ^ & May 17, 2000 & 1,151 \\
\hline OAKWOOD HOMES CORP. ^ & November 15,2002 & 1,149 \\
\hline COVAD COMMUNICATIONS & August 15, 2001 & 1,148 \\
\hline MOBILEMEDIA COMMUNICATIONS, INC. ^ & January 30, 1997 & 1,143 \\
\hline TELIGENT INC & May 21, 2001 & 1,132 \\
\hline INACOM CORP. ^ & June 16, 2000 & 1,104 \\
\hline GRAND UNION COMPANY & June 24, 1998 & 1,061 \\
\hline METALS USA, INC. & November 14, 2001 & 1,049 \\
\hline SUNTERRA CORP & May 31,2000 & 1,021 \\
\hline CALDOR CORPORATION ^^ & September 18,1995 & 1,006 \\
\hline
\end{tabular}

The symbols * and $\wedge$ represent firms filing for bankruptcy because of fraud and firms that did not survive the bankruptcy process, respectively. 